\title{
SIMPLE HOMEMADE APPARATUS FOR HARVESTING UNCULTURED MAGNETOTACTIC MICROORGANISMS
}

\author{
Ulysses Lins $^{1 *}$; Flavia Freitas ${ }^{1}$; Carolina Neumann Keim²; Henrique Lins de Barros ${ }^{3}$; \\ Darci Motta S. Esquivel ${ }^{4}$; Marcos Farina ${ }^{2}$
}

\begin{abstract}
${ }^{1}$ Departamento de Microbiologia Geral, Instituto de Microbiologia Professor Paulo de Góes, Universidade Federal do Rio de Janeiro, Rio de Janeiro, RJ, Brasil; ' ${ }^{2}$ nstituto de Ciências Biomédicas, Universidade Federal do Rio de Janeiro, Rio de Janeiro, RJ, Brasil; ${ }^{3}$ Museu de Astronomia e Ciências Afins, Rio de Janeiro, RJ, Brasil; ${ }^{4}$ Centro Brasileiro de Pesquisas Físicas, Rio de Janeiro, RJ, Brasil.
\end{abstract}

Submitted: June 12, 2002; Returned to authors for corrections: October 18, 2002; Approved: June 26, 2003

\begin{abstract}
A simple apparatus for harvesting uncultured magnetotactic microorganisms is described. This apparatus consists of a glass container with two openings. A large opening on the topside is used to introduce the sediment and water. The sediment and water are previously stored in loosely capped bottles previously tested for the presence of magnetotactic bacteria. The apparatus is exposed to a properly aligned magnetic field of a homemade coil and the bacteria are removed through the capillary end of the second opening of the container. Harvested bacteria can then be used to ultrastrucutral studies using electron spectroscopic imaging. Large numbers of magnetotactic bacteria consisting of cocci and rod-shaped cells were efficiently collected from different environments. This apparatus is useful for microbiological studies on uncultured magnetotactic bacteria, especially in molecular approaches for phylogenetic investigations that give information on the natural diversity of microbial communities.
\end{abstract}

Key words: Magnetotactic bacteria, harvesting uncultured bacteria, electron microscopy

\section{INTRODUCTION}

Magnetotactic bacteria are directly influenced by magnetic fields, specially the geomagnetic field (7). Magnetotactic bacteria orient and navigate along magnetic field lines because they produce nanometer-sized organelles called magnetosomes. Each magnetosome consists of a magnetic crystal, magnetite $\left(\mathrm{Fe}_{3} \mathrm{O}_{4}\right)$ in most cases, enveloped by a membrane (14). The number of magnetosomes varies within bacteria but usually they form chains that impart cells a magnetic moment that is sufficient to orient the cell body with respect to the magnetic field. Magnetotactic bacteria occur in a variety of forms that include coccoid, vibroid, and spirilla.

Potential biotechnological applications of magnetotactic bacteria that take advantage of their magnetotactic behavior were developed such as the radionuclide recovery from contaminated waters $(2,3)$.
The ability to migrate along magnetic field lines can be used to retrieve magnetotactic cells from the sediment. Several approaches were applied to magnetically separate and enrich magnetotactic microorganisms from sediments (10). The simplest way of obtaining magnetotactic bacteria is an enrichment culture, which is obtained by the simulation of natural niche in the laboratory. In its most common configuration, the sediment and the overlaying water collected from a water body is placed on a loosely capped bottle and stored for several weeks in dim light at appropriate temperature (10). To harvest the enriched magnetotactic bacteria, a pair of magnets is attached to opposite sides of the walls of the bottles and the bacteria are removed with a Pasteur pipette and used in subsequent studies (11).

A capillary racetrack method was used to study the movement of magnetotactic bacteria (17) and a special capillary tube was

\footnotetext{
* Corresponding author. Mailing address: Departamento de Microbiologia Geral, Instituto de Microbiologia Prof. Paulo de Góes, CCS, Bl. I. Universidade Federal do Rio de Janeiro. 21941-590, Rio de Janeiro, RJ, Brasil. Fax: (+5521) 560-8344. E-mail: ulins@micro.ufrj.br
} 
used to observe the zone migration in magnetic cocci (4). Alternatively, several enrichment cultures that use some sort of cultivation were also developed for isolation and phylogenetic investigations of magnetotactic microorganisms (15). Adamkiewicz et al. (1) inoculated a tube containing semisolid translucent agar-mud with bacteria. The enriched medium contained microorganisms that formed a stratified layer with the agar and could be removed for subsequent studies. A more sophisticated method that involves several steps of incubation, enrichment in medium and isolation from colony formation, but do not use magnetotaxis was also developed (13).

Despite their almost universal distribution in aquatic habitats, most magnetotactic microorganisms cannot be easily cultivated. They have proven to be difficult to keep under laboratory conditions probably because of their demands of stratified gradients and oxygen concentration for optimal growth (6). Most studies on magnetotactic microorganisms are on uncultured samples. Because no strictly selective media exist for cultivation of magnetotactic bacteria, the effective separation of these bacteria is critical in their study. We have been using a procedure that uses a simple homemade coil and a specially designed glass apparatus to separate a large number of magnetotactic microorganisms from enrichment cultures (16). Here, we describe this procedure and its application for collecting uncultured magnetotactic bacteria from aquatic sediments. This method is useful for microbiological studies on uncultured magnetotactic microorganisms, especially in molecular approaches for phylogenetic investigations as opposed to cultivation-based methods that are incomplete and give selective information on the natural diversity of microbial communities.

\section{MATERIALS AND METHODS}

\section{Sampling and storage of magnetotactic microorganisms}

Samples were collected in several lagoons close to Rio de Janeiro city: "Lagoa de Itaipu" (marine), "Lagoa de Cima" (fresh water), "Lagoa Rodrigo de Freitas" (brackish). Sediment and water in a proportion of approximately 1:2 were stored in loosely capped bottles (Fig. 1a) and left undisturbed for several weeks under dim light at room temperature. During this period, the sediment of several bottles stratified and formed several distinguishable layers (Fig. 1a, arrow).

\section{Magnetic harvesting of bacteria}

Periodically bottles were checked for the presence of magnetotactic bacteria. For this, a drop of sediment was exposed to a properly aligned magnetic field of an ordinary magnet and observed under a light microscope. In the southern hemisphere, bacteria swim to the south, which it means that north pole of the magnet faces the drop edge where the bacteria concentrate. If magnetotactic bacteria were present in the drop, the enriched bottle was used for magnetic isolation. Turning the magnet and observing the reversal of the swimming direction of the bacteria confirmed the presence of magnetotactic bacteria.

For harvesting magnetotactic bacteria, we used a specially designed glass device shown in Fig. 1b, which was made from a $250 \mathrm{ml}$ Erlenmeyer flask. The glass device presents two holes. The larger hole (Fig. 1b; black arrow) is located in the large top surface of the apparatus and is used to fill the volume with sediment (Fig. 1b, white arrowhead) and water from the enriched bottle (Fig. 1b, white arrow). A smaller capillary end is located at one of the lateral sides of the device. This end can, in some configurations, present an additional chamber filled with filtered
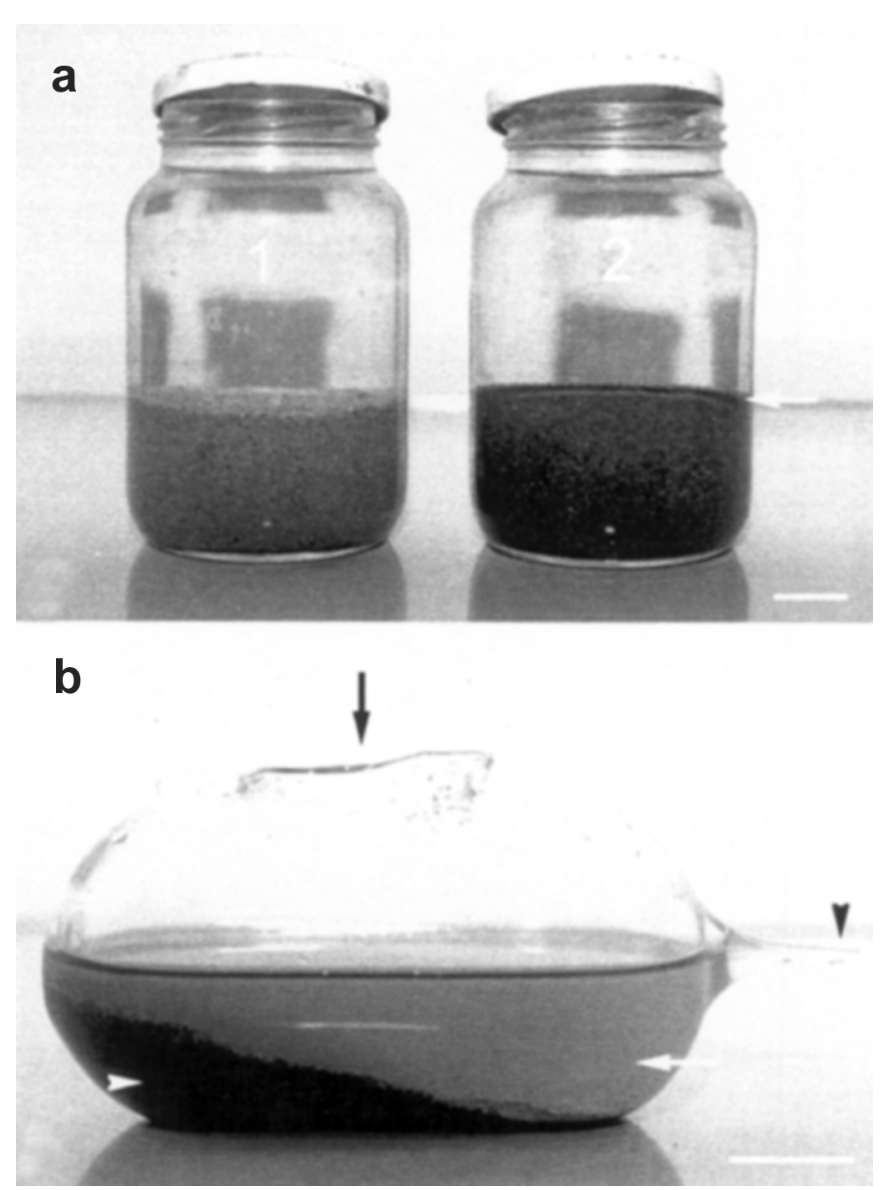

Figure 1. Natural enrichments (a) of magnetotactic bacteria and glass apparatus (b) for their magnetic concentration. (a) Sediment and water from collection site are stored in bottles (1). Several weeks after collection, in some bottles (2), the sediment stratifies (arrow). For magnetic collection, the glass apparatus (b) with large opening (black arrow) through which the sediment (white arrowhead) and water (white arrow) are introduced up to the level of the capillary end (black arrowhead) is used. Scale bar indicates $2 \mathrm{~cm}$ in (a) and $4 \mathrm{~cm}$ in (b). 
sediment water (5) which yield more purified samples of magnetotactic bacteria. Firstly the small capillary hole is filled with millipore filtered sample water. Afterwards, the device is filled with sediment and water until the small hole is surpassed. Care was taken to avoid small sediment particles to obstruct this hole otherwise bacteria would not reach the end of the tube. To minimize this effect, the sediment was deposited closer to the closed side, opposite to the capillary end. After filling, the glass device was placed on a home-made coil which consisted of a thin wire that coiled around a polyvinyl chloride (PVC) tube (Fig. 2a). The wire was connected to a small power supply with a maximum nominal voltage of $12 \mathrm{~V}$ (Fig. 2a). The coiled tube generated a properly aligned homogenous magnetic field, which was checked with a compass for proper orientation. The glass device was exposed to the magnetic field (approximately 5 Gauss) for at least 15 minutes and then a small quantity of water with concentrated bacteria (Fig. 3b) was removed with a capillary tube and observed under a light microscope to check for the evaluation of the number of magnetotactic microorganisms. If a relatively large number of bacteria were present in the drop, the enriched bacteria on the glass tube was removed and processed for electron microscopy. An alternative way of obtaining a higher number of magnetotactic bacteria was to use glass devices similar in shape but larger than the one described in Fig. 1b to store bacteria from the environment, and introduce this device directly on the coil for bacteria recovery. This procedure reduces the aeration of the sample and the stratification of the sediment during recovery, minimizing the changes on the sample caused by the described method.

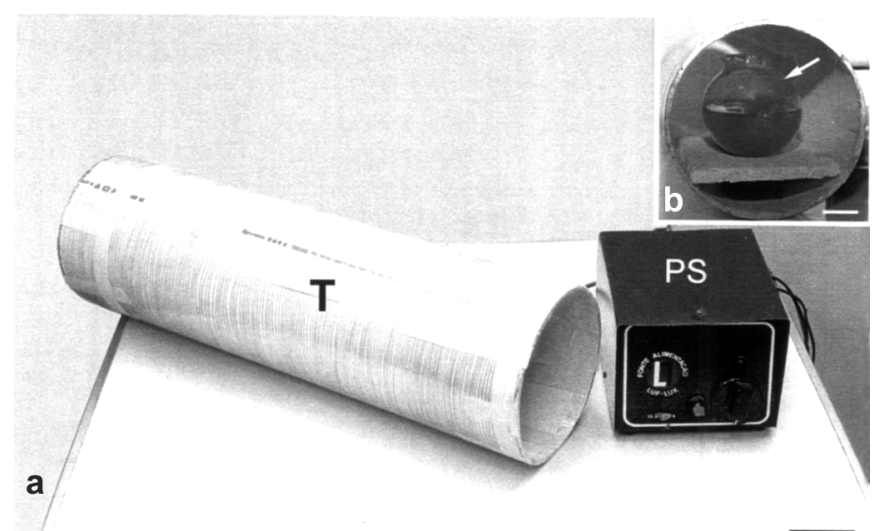

Figure 2. Harvesting of magnetotactic bacteria. (a) To harvest magnetotactic bacteria, a homemade coil consisting of a wired PCV tube (T) is attached to a power supply (PS) is used. (b) The glass apparatus (arrow) is placed inside the coil and exposed to a magnetic field for 15 minutes. Scale bar indicates $7.5 \mathrm{~cm}$ in (a) and $4 \mathrm{~cm}$ in (b).

\section{Preparation of grids for electron microscopy}

For the observation of magnetotactic bacteria by electron microscopy, formvar films were produced from a $0.3 \%$ formvar solution in chloroform. The film was spread over a clean water surface and grids were carefully deposited over the film. Grids were captured from the water surface with clean glass slides. With this technique, grids were sandwiched between the film and glass slide. This arrangement prevented the water from the samples from accumulating under the grid, which would difficult the spreading of the bacteria for observation. We used electron spectroscopic imaging technique to probe the morphology and structure of uncultured bacteria. For this, a drop of enriched bacteria was deposited on a formvar coated grid. The drop was placed partially covering the grid surface (Fig. 4a). A magnet was positioned on the opposite side of the drop with a alignment of the magnetic field in such a way that the bacteria would swim to the side close to the middle of the grid. After several minutes, bacteria were accumulated on the drop edge (Fig. 4a, arrow). The sediment water was carefully replaced with distilled water by the side of the drop that did not cover the grid. This procedure prevents the growth of salt crystals during air-drying. After several washes, the grid was air-dried. Usually, bacteria spread evenly in some grid fields (Fig. 4b).

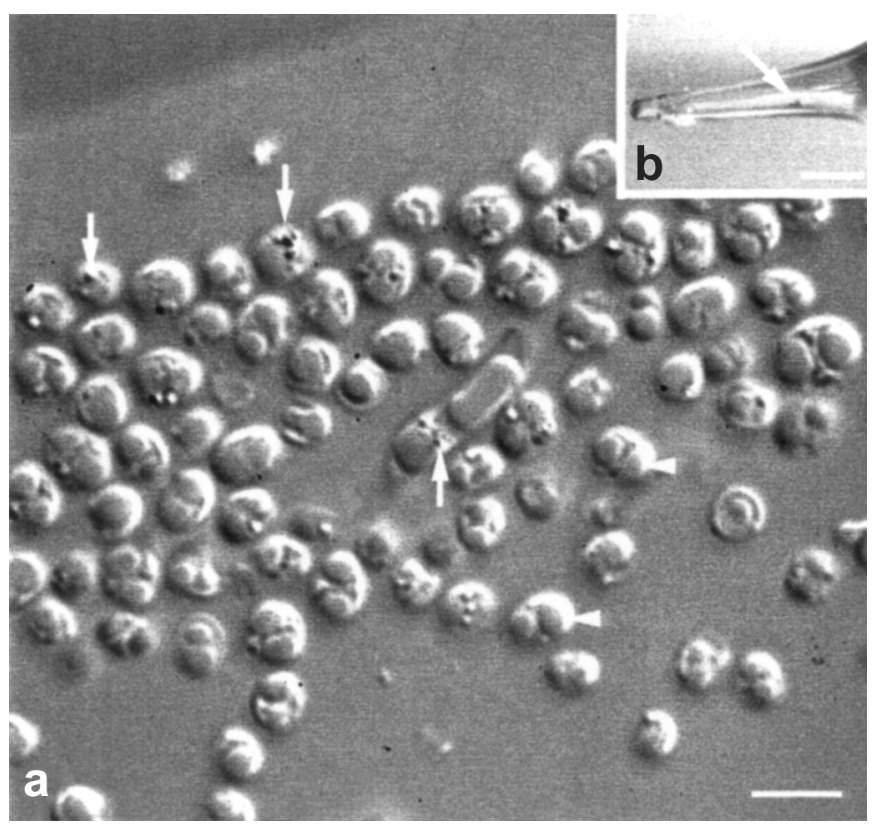

Figure 3. (a) Light microscopy image of magnetotactic cocci from Itaipu lagoon. Most bacteria present dark regions (arrows) corresponding to magnetosome chains and granules (arrowheads). (b) Capillary end of the glass apparatus used to harvest bacteria in (a). A mass of magnetotactic bacteria (arrow) can be observed. Scale bar indicates $5 \mu \mathrm{m}$ in (a) and $1 \mathrm{~cm}$ in (b). 


\section{Electron spectroscopic imaging}

For imaging uncultured magnetotactic bacteria, we used energy-filtering transmission electron microscopy, which is an imaging technique that allows the observation of thick samples (12) and gives good results for magnetotactic bacteria $(8,9)$. Briefly, this technique is based on a built-in spectrometer into the electron microscope column that spatially separates beam electrons
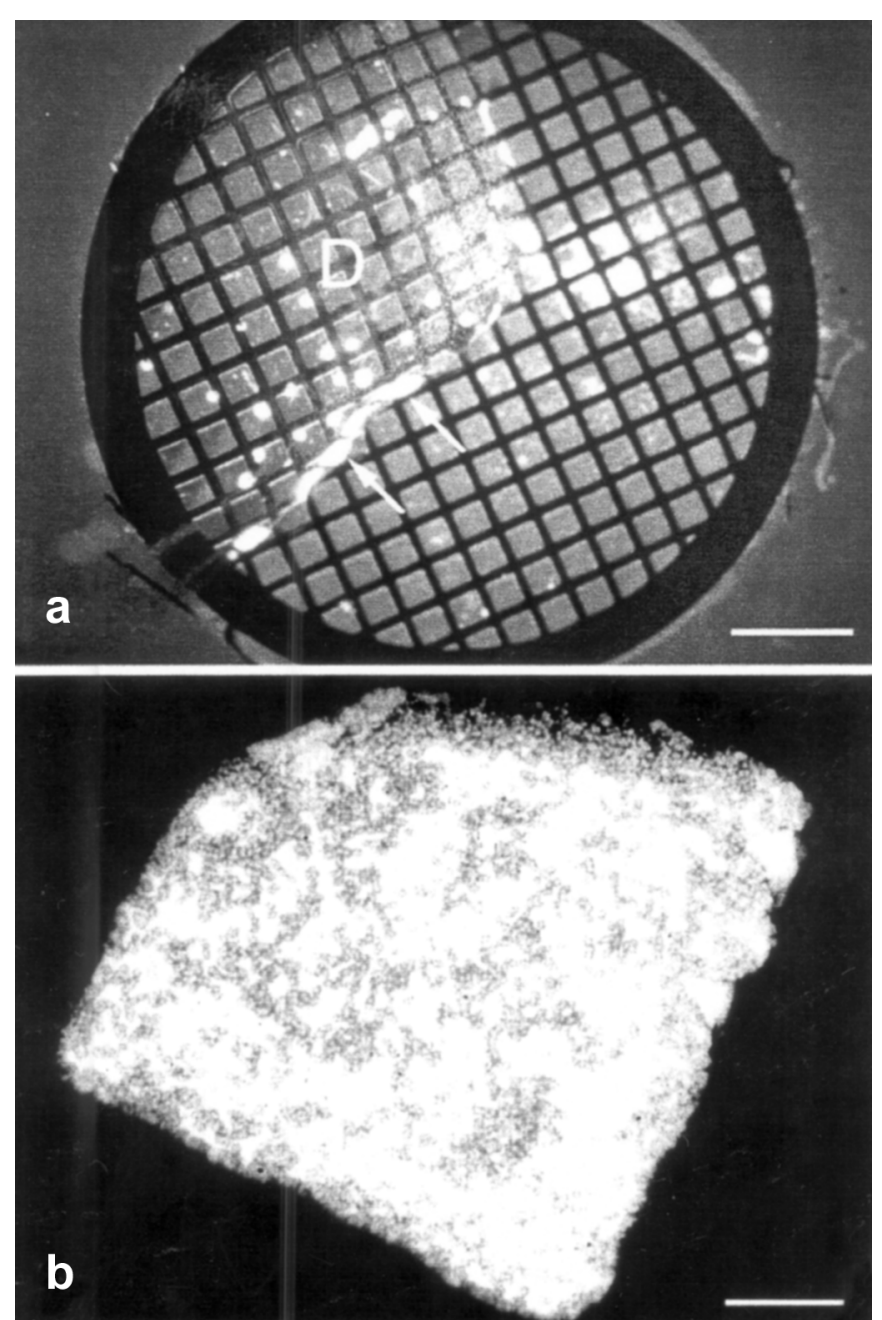

Figure 4. Preparation of magnetotactic bacteria for transmission electron microscopy and electron spectroscopic image. (a) Darkfield light microscopy image of a grid. A drop (D) of water with harvested bacteria is placed on a formvar-carbon coated electron microscopy grid. A magnet (not seen in the figure) was placed in a way to drive the bacteria to one of the limits of the drop, near the center of the grid. Clouds of magnetotactic bacteria (arrows) accumulated at the drop edge. (b) To prepare the grid to electron microscopy, the water is carefully replaced by distilled water, and the grid is air-dried. In some grid squares, the bacteria are homogeneously distributed. Scale bar indicates $0.5 \mathrm{~mm}$ in (a) and $30 \mu \mathrm{m}$ in (b). according to their energy loss after interaction with sample atoms. An energy-selecting slit is placed in the energy dispersive plane of the spectrometer, and narrows the energy range of imaging electrons. Moving the spectrum through the slit determines the energy loss range of imaging electrons. In this way, contrast variations in the image can be tuned for better visualization of internal structures in relatively thick specimens because of differences in mass thickness. For this, grids with isolated bacteria were observed under a Zeiss 912 transmission electron microscope operating at voltages of 80,100 or $120 \mathrm{kV}$. The objective aperture was of 8.3 or $4.2 \mathrm{mrad}$ and an energy selecting aperture of $20 \mathrm{eV}$ was used. Imaging was done by heuristically tuning the contrast for best imaging conditions (9). Images were recorded on Kodak SO163 film, which was developed, scanned on a Flexitight scanner and printed on a FujiPictrography 3000 printer.
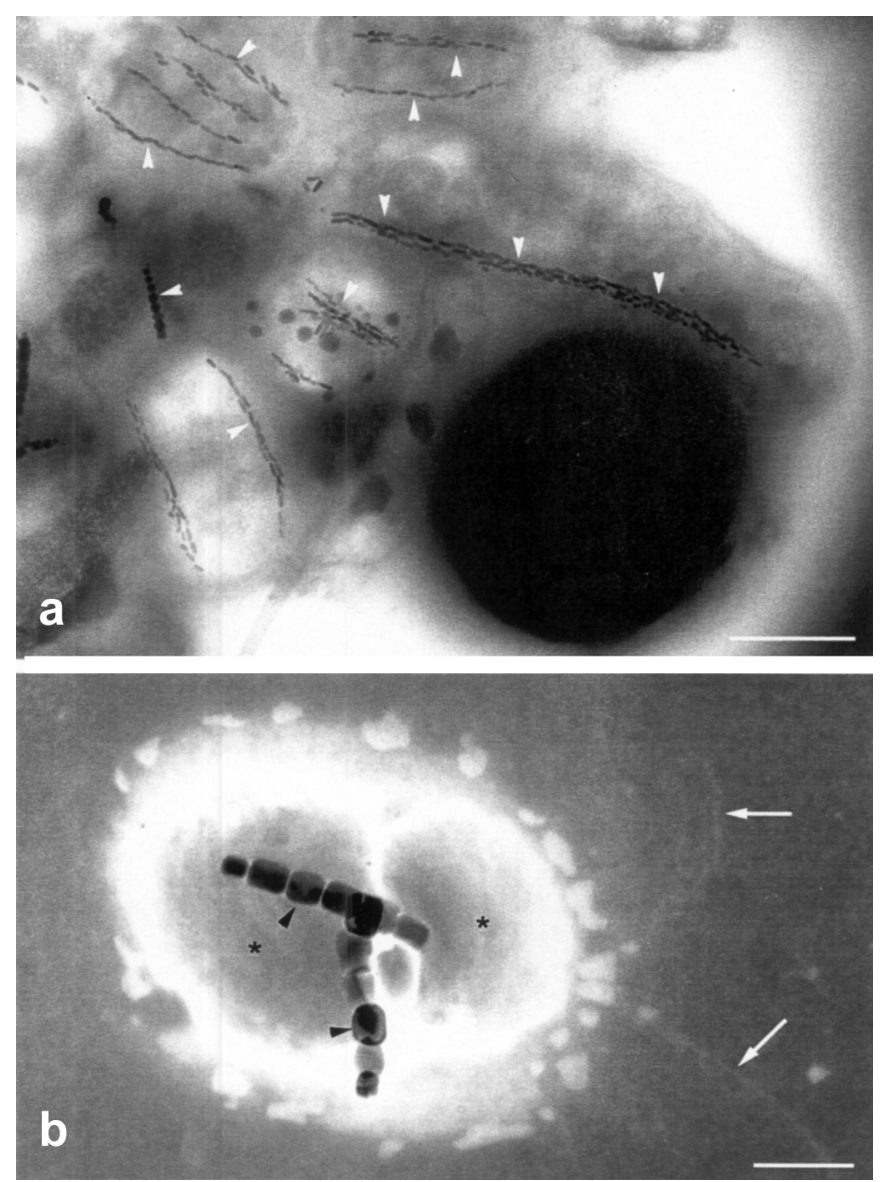

Figure 5. Electron spectroscopic image of magnetotactic bacteria near the drop edge. (a) Different morphological types and magnetosomes arrangement (arrows)can be visualized. (b) Magnetotactic bacterium from Itaipu lagoon, showing the chains of magnetosomes (arrowheads) and phosphorus-rich granules (stars). Two flagella (arrows) can also be seen. Scale bar indicates $1 \mu \mathrm{m}$ in (a) and $400 \mathrm{~nm}$ in (b). 


\section{RESULTS AND DISCUSSION}

Because of their directed migration in magnetic fields, enriched magnetotactic bacteria can be easily collected in large numbers with our approach (Figs. 3a and 3b). If the number of magnetotactic bacteria was high enough, a mass of microorganisms could be visualized in the tube of the glass apparatus (Fig. 3b, arrow). Most magnetotactic bacteria retrieved from Itaipu lagoon were cocci. Rod-shaped bacteria were occasionally found (Fig. 3a). Other sampling sites presented a variety of morphological types. After isolation from the sediment, magnetotactic bacteria were retrieved in large numbers and could be used for transmission electron microscopy studies of natural population of magnetotactic bacteria by electron spectroscopic imaging.

The preparation of grids for electron microscopy studies was relatively easy and allowed the study of bacteria at ultrastructural level. In several minutes, the magnetotactic bacteria could be visualized at the drop edge through a dark field light microscopy (Fig. 4a, arrows). We found negligible differences between water and fixative solution in this step. Most of the bacteria were crowded close to the drop edge (Fig. 5a). Several grid squares were uniformly filled with bacteria (Fig. 5b).

To better visualize magnetotactic bacteria and their magnetosomes, energy-filtering transmission electron microscopy was used. Electron spectroscopic imaging allows the observation of magnetosomes inside magnetotactic microorganisms with unique clarity (9). We could directly visualize the magnetosome chains (Fig. 5a, arrowheads). The number, size and morphology of magnetosomes (Fig. 5b, arrowheads) and other cellular structures such as granules (Fig. $5 \mathrm{~b}$, stars) could be directly observed. The spatial disposition of structures inside the bacterial cell could be observed and associated with the disposition of flagella (Fig. 5b, arrows) of the respective cells. The possibility of retrieving large number of cells and the association of a powerful technique such as electron spectroscopic imaging can improve our knowledge of the organization of magnetotactic bacteria as well as functional aspects of magnetotaxis as a phenomenon.

Our isolation method depends on magnetotaxis to retrieve large number of magnetic bacteria. It relies on the fact that orientation and magnetic separation can only be used if magnetotactic bacteria are both motile and possess a magnetic moment sufficient to overcome the thermal perturbations of the medium. However, non-magnetic forms of magnetic bacteria were reported in cultured bacteria (14). This indicates that some of the magnetic bacteria present in the environment may not be retrieved because they do not express magnetosomes at the time of collection. A method that does not use magnetotaxis to retrieve magnetic bacteria has been developed (13). This method consists of several steps that include incubation of sediments, enrichment of bacteria in medium and isolation by colony formation. Although our approach may not retrieve all possible forms of magnetotactic microorganisms, it is easy to use and retrieve a large number of magnetotactic bacteria. We believe that both methods are complementary and can be used in different situations or different purposes.

Another point that deserves attention is the fact that, in our approach, magnetic bacteria are only isolated when magnetic fields much higher than the geomagnetic one are used. So, it is reasonable to assume that some of the harvested bacteria may have been collected because of the higher magnetic fields applied. This means that some of the microorganisms isolated may not use magnetotaxis as an efficient mechanism for navigation, in spite of the fact that they produce magnetosomes (10).

In conclusion, our method of harvesting magnetotactic bacteria is easy to implement, inexpensive and can be used to recover a large number of microorganisms for environmental, structural and diversity studies purposes. It is also a simple way of demonstrating magnetotaxis for educational purposes.

\section{ACKNOWLEDGEMENTS}

Financial support from Brazilian agencies and programs: FUJB, CNPq, FAPERJ, Pronex and CAPES-PROCAD.

\section{RESUMO}

\section{Aparato simples para captura de microrganismos magnetotácticos não cultivados}

Descrevemos um aparato simples para a captura de microrganismos magnetotácticos não cultivados. Este aparato consiste em um recipiente de vidro com duas aberturas. Uma abertura maior na parte superior é usada para introduzir o sedimento e a água. O sedimento e a água são previamente armazenados em um recipiente semitampado, previamente testado para a presença de bactérias magnetotácticas. $\mathrm{O}$ aparato é exposto a um campo magnético, devidamente alinhado, em uma bobina feita a mão e as bactérias são removidas pela extremidade capilar da segunda abertura do recipiente. As bactérias coletadas podem então ser usadas em estudos ultraestruturais usando a técnica de imagem espectroscópica eletrônica. Um grande número de bactérias consistindo de cocos e bastonetes foi eficientemente coletado de diferentes ambientes. Este aparato é útil para estudos microbiológicos sobre microrganismos magnetotácticos não cultiváveis, especialmente em abordagens moleculares para investigações filogenéticas que fornecem informações sobre a diversidade natural de comunidades microbianas.

Palavras-chave: Bactérias magnetotácticas, captura de bactérias não cultivadas, microscopia eletrônica 


\section{REFERENCES}

1. Adamkiewicz, V.W.; Authier, A.; Dumont, S.; Garzon, S.; Leduc, S.; Morency, D.; Nakhostin, N.; Strykowski, H. Simple procedure for enriching and cultivating magnetic bacteria in low agar-mud medium. J. Microbiol. Meth., 13: 255-258, 1991.

2. Bahaj, A.S.; James, P.A.B.; Moeschler, F.D. Wastewater treatment by bio-magnetic separation: a comparison of iron oxide and iron sulphide biomass recovery. Water Sci. Tech., 38: 311-317, 1998.

3. Bahaj, A.S.; Croudace, I.W.; James, P.A.B.; Moeschler, F.D.; Warwick, P.E. Continuous radionuclide recovery from wastewater using magnetotactic bacteria. J. Mag. Mag. Mat., 184: 241-244, 1998.

4. Carlile, M.J.; Dudeney; A.W.L. Zonation in migrating magnetococci. J. Gen. Microbiol., 139: 1671-1680, 1993.

5. Esquivel, D.M.S.; Lins de Barros, H.G.P.; Farina, M. Diversity of magnetic crystals found in magnetotactic bacteria. In: Frankel, R.; Blakemore, R. (eds). Iron Biominerals, Plenum Publishing Corporation, New York, 1990, p. 117-126.

6. Frankel, R.B.; Bazylinski, D.A.; Schuler, D. Biomineralization of magnetic iron minerals in bacteria. Supramol. Sci., 5: 383-390, 1998.

7. Lins de Barros, H.G.; Esquivel, D.M.; Farina, M. Magnetotaxis. Sci. Prog., 74: 347-359, 1990.

8. Lins, U.; Farina, M.; Lins de Barros, H.G. Contribution of electron spectroscopic imaging to the observation magnetic bacteria magnetosomes. Microsc. Eletr. Biol. Cel., 16: 151-162, 1992.
9. Lins, U.; Freitas, F.; Keim, C.; Farina, M. Electron spectroscopic imaging of magnetotactic bacteria: magnetosome structure, morphology and diversity. Microsc. Microanal., 6: 463-470, 2000.

10. Mann, S.; Sparks, N.H.; Board, R.G. Magnetotactic bacteria: microbiology, biomineralization, palaeomagnetism and biotechnology. Adv. Microb. Physiol., 31: 125-181, 1990.

11. Moench, T.T.; Konetzka, W.A. A novel method for the isolation and study of a magnetotactic bacterium. Arch. Microbiol., 119: 203212, 1978.

12. Reimer, L. Energy-filtering transmission electron microscope. $A d v$. Electron. Phys., 81: 43-126, 1991.

13. Sakaguchi, T.; Tsujimura, N.; Matsunaga, T. A novel method for isolation of magnetic bacteria without magnetic collection using magnetotaxis. J. Microbiol. Meth., 26: 139-145, 1996.

14. Schuler, D.; Frankel, R.B. Bacterial magnetosomes: microbiology, biomineralization and biotechnological applications. Appl. Microbiol. Biotechnol., 52: 464-473, 1999.

15. Schuler, D.; Spring, S.; Bazylinski, D.A. Improved technique for the isolation of magnetotactic spirilla from a freshwater sediment and their phylogenetic characterization. Syst. Appl. Microbiol., 22: 466$471,1999$.

16. Spring, S.; Lins, U.; Amann, R.; Schleifer, K.H.; Ferreira, L.C.; Esquivel, D.M.; Farina, M. Phylogenetic affiliation and ultrastructure of uncultured magnetic bacteria with unusually large magnetosomes. Arch. Microbiol., 169: 136-147, 1998.

17. Wolfe, R.S.; Thauer, R.K.; Pfennig N. A capillary racetrack method for isolation of magnetotactic bacteria. FEMS Microbiol. Ecol., 45: 31-35, 1987. 